\title{
Customer relationship management in the agricultural machinery market
}

\author{
Amanda Letícia Pit Nunes ${ }^{1}$ Otavio Jorge Grigoli Abi-Saab ${ }^{2}$ Ricardo Ralisch ${ }^{2}$
}

\begin{abstract}
'Programa de Pós-graduação em Agronomia, Departamento de Agronomia, Centro de Ciências Agrárias, Universidade Estadual de Londrina (UEL), Campus Universitário, 86051-970, Londrina, PR, Brasil. E-mail: amanda.pit@outlook.com. Corresponding author.

${ }^{2}$ Departamento de Agronomia, Universidade Estadual de Londrina (UEL), Londrina, PR, Brasil.
\end{abstract}

\begin{abstract}
Customer Relationship Management can be regarded as a business approach. The objective was to know the customers, meet their expectations, and thus build customer loyalty. Although, the agricultural sector makes significant economic contributions to the Brazilian market and induces sharp competition among its companies, a huge opportunity still presents itself for the diffusion and implementation of CRM in the agricultural machinery sector. This study aimed to highlight the importance of customer management, by introducing the customer relationship management (CRM) concept. This is possible in the event of reselling agricultural machines, with the intention of retaining the customers and raising the profitability of these companies. It is necessary to understand CRM as more than a mere a concept or a tool. It is a business strategy, an endeavor that must be endorsed by the entire company. The concessionaire must be perceived as greater than a mere reseller. It is to be viewed rather as a problem solver, as one who offers services that are high in quality and meet client specifics. Key words: concessionaire, customer loyalty, CRM, marketing.
\end{abstract}

Customer relationship management no setor de máquinas agrícolas

\begin{abstract}
RESUMO: $O$ Customer Relationship Management pode ser considerado uma estratégia empresarial que visa conhecer seus clientes para atender suas expectativas, na intenção de fidelizá-los. Apesar da importância econômica do setor agrícola para o mercado brasileiro e o acirramento concorrencial entre suas empresas, há grande oportunidade para a difusão e implantação do CRM no setor de máquinas agricolas. O objetivo do presente trabalho foi ressaltar a importância da gestão dos clientes, inserindo o conceito de gestão do relacionamento com clientes no caso de revendas de máquinas agrícolas, com o intuito de reter clientes e aumentar a rentabilidade dessas empresas. O CRM deve ser abordado além de um conceito ou uma ferramenta, mas como estratégia de negócio, uma missão que deve ser adotada por toda a empresa. A concessionária deve ser reconhecida, mais que apenas uma revendedora, mas como solucionadora de problemas, prestando serviço de qualidade e adaptado às especificidades de cada cliente.

Palavras-chave: concessionária, fidelização de clientes, gestão de relacionamento de clientes, marketing.
\end{abstract}

\section{INTRODUCTION}

As agribusiness made rapid strides and developed, it was accompanied by a visible explosion in technification and mechanization in the agricultural sector, which stimulated a greater degree of competitiveness in the agricultural machinery market. Therefore, the agricultural equipment dealers appreciated the importance of knowing and retaining their clientele. Giant companies from all the economic sectors are recognized for their customer retention and high profitability.

In terms of the marketing strategies, the prevailing product quality and price may not be adequate differentiators to facilitate gaining or maintaining a customer, justifying the birth of managing a relationship with a customer or Customer Relationship Management (CRM).

$\mathrm{CRM}$ is; therefore, interpreted as a business approach to understand and impact customer behavior through relevant communications, in order to enhance their purchases, retention, loyalty and profitability (SWIFT, 2001). CRM can be interpreted as a company policy with the aim of knowing and modifying the desired relationship with the customers, in order to make the right recommendation at the right time for the right customers. Another way to understand it is as a process of attaining and 
systematizing the details of the customers' particulars with the aim of knowing them better and categorize them under various degrees of profitability for the company. CRM includes a technological slant and many software companies employ this expression to trade their information, customer and marketing management systems.

Unquestionably, the objective for implementing CRM is the appreciable growth in company performance which is a characteristic of marketing strategies (KRASNIKOV et al., 2009). Without losing sight of this goal, the company must first systematize its efforts to improve its understanding of its customers with the intention of attracting, influencing, maintaining, enlarging the number and retaining its most prized customers, who assume a bigger part than they did earlier (NGUYEN \& MUTUM, 2012).

According to PAYNE (2006), CRM is a holistic strategic method of managing customer relationships to build shareholder value. PAYNE also purported that CRM opens up more options for utilizing the data and particulars to foster a clearer understanding of the client and thus being able to more satisfactorily effect these relationship marketing strategies; however, this interpretation does not limit CRM to being merely a database system or technological tool.

As the term CRM was initially understood to be a mere technological solution, PAYNE (2006) presented the statistics given here: $60 \%$ of CRM projects end in failure, $70 \%$ of the CRM initiatives will be unsuccessful in 18 months and 69\% of CRM projects will negligibly or not at all influence the business results. In this context, the author suggested that to succeed in implementing a CRM project, the entire company must possess total commitment, and be focused on the strategic vision of building shareholder value. This is accomplished by expanding the tactical customer relationships, by combining the inherent power of information technology and Relationship Marketing techniques to consolidate and maintain long-term and rewarding relationships.

According to STRAUSS \& FROST (2002) the main reasons for CRM to fail are: (i) the assumption that the technology itself is the solution; in fact, technology is relevant only if it is combined with strategic thinking; (ii) absence of managerial support arising from the paucity of information regarding the opportunities afforded by CRM; (iii) deficiency of customer-oriented culture; (iv) dearth of a clearly-outlined master plan and goals; (v) lack of a process redefinition; (vi) insufficient information and low quality of data; (vii) faulty control of the processes of change at all levels of the company; and (viii) detached behavior of those employing the system (CRM).

The rapid technological development supplies an increasing number of tools that enables the company to develop a better understanding of the behavioral patterns of its clients, apart from gaining insight into their needs and inclinations. Having this information, it is the responsibility of the company to modify and employ these tools to customize the marketing offers to suit each customer sector.

Although the agricultural sector is still highly traditional, updating and investing was done for the companies of the branch and the information was gathered and organized to optimize the results. However, obstacles are still present that hinder the definition and implementation of CRM in the companies linked to the agricultural machinery sector, and the reasons are listed: 1) most often the farmers are hesitant to collect the information; 2) insufficient knowledge regarding the company and difficulty in identifying information that is pertinent to their business and its application at a later point in time; 3 ) poorly trained sales staff and/or staff who are unable to obtain, systematize and use this information; 4) absence of software specifically tailored for the resale of agricultural machinery and lack of a database related to these dealers.

This article aimed to highlight the significance of customer management, incorporating the idea of managing customer relationship in the context of reselling the agricultural machines, with the sole intention of retaining the clients and escalating the profitability of these companies.

\section{DEVELOPMENT}

\section{Competitiveness of the agricultural market}

Brazil, basically an agricultural country, and $21.5 \%$ of the Gross Domestic Product (GDP) in 2015 came from agribusiness (CEPEA, 2015). As modernization has made inroads into agricultural production, a visible spurt in productivity has been observed, with the continuous development of genetically modified varieties and phytosanitary products, as well as the intense expansion and rise in the introduction of handling techniques and the employment of constantly enhanced modern machines and tools.

The expanding agribusiness enhanced positively the Brazilian economy, as is evident from its contribution to the trade balance (Figure 1). 


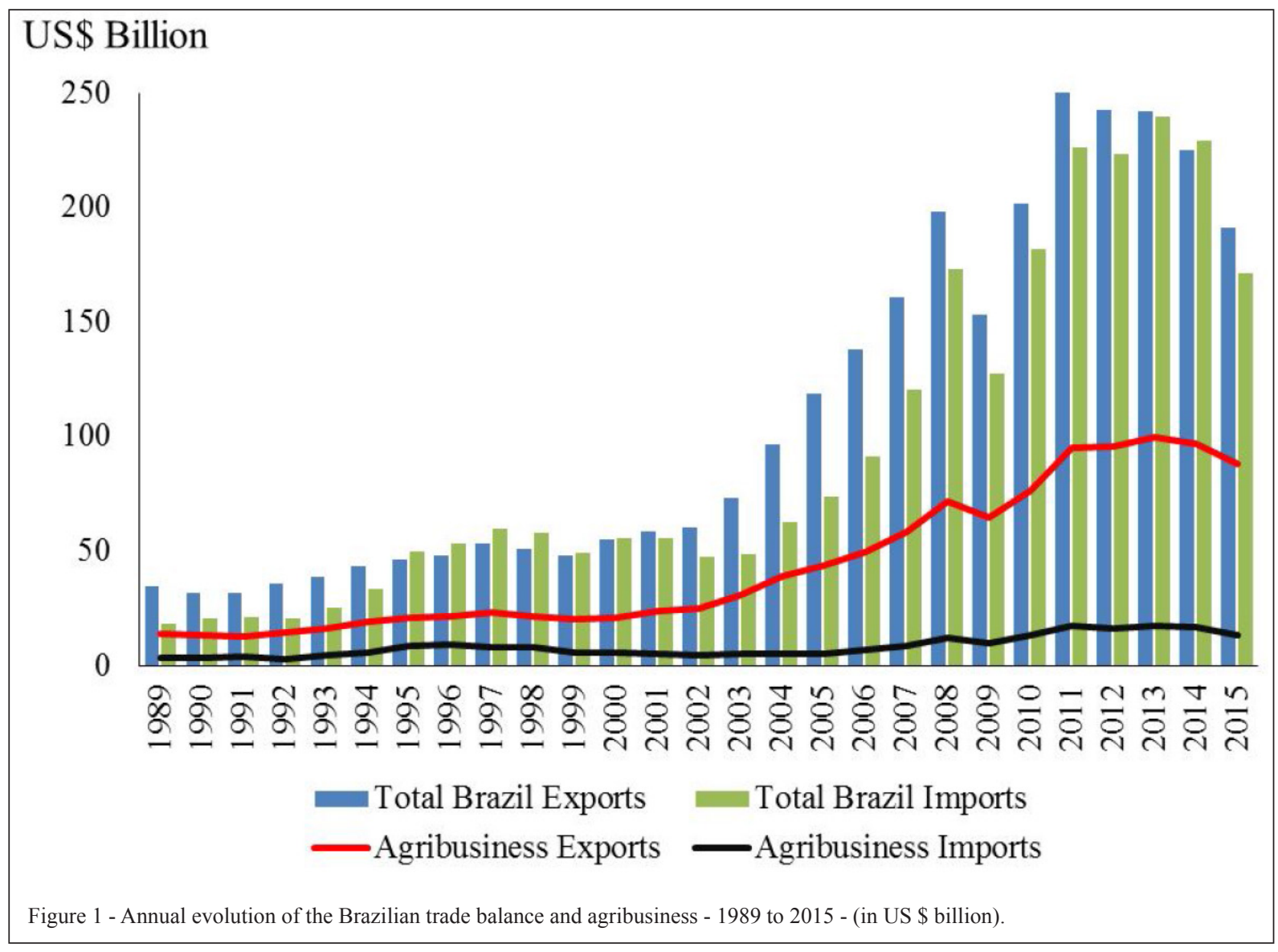

The last 27 years have demonstrated that $40.7 \%$ of Brazilian exports have been from the agribusiness sector. Brazilian agribusiness exports have shot up by more than six times, since 1989 . Conversely, the imports in the sector account for only $11 \%$ in the same time period (27 years), revealing its strong contribution to the Brazilian trade balance.

Figure 2 clearly demonstrated the effective evolution of the agribusiness trade balance, which has showed no negative balance since 1989, but rather boosted its balance through the years, touching US $\$ 80.134$ billion in 2014. However, fluctuations have been noted in the Brazilian trade balance, on both the positive and negative sides, showing a downward trend since 2006, to a negative balance in 2014 (US\$ -3.959 billion).

As agribusiness expanded and became modernized, one of the major worrisome issues has been to identify the means to boost productivity, to the detriment of the expansion of agricultural areas. Providing adequacy and updating the farm equipment in the rural regions is one method of dealing with this concern. The introduction of precision agriculture had a positive impact, initiating to modernize and optimize the utilization of agricultural machinery, geting higher returns.

In table 1 , the steady rise in the sales of domestic agricultural machinery is seen from 2000 to 2015. These upward surged was an indication of the expanding Brazilian agribusiness, and introduced new interests and concepts, which are inserted in this sector. The upswing in the sales and domestic output of the agricultural equipment induced the entrepreneurs to be concerned about their market shares and inspired them to utilize marketing tools and strategies to justify and heighten their performance.

Apart from the normal avenues of setting up exhibition stands and product demonstrations at various fairs, both at the field and farm levels, resellers of agricultural machinery have also been focused on advertising campaigns, maintaining up-to-date websites and boosting the market share in their parts of the country. In light of this sharper competitiveness, establishing customer loyalty has been now accepted 


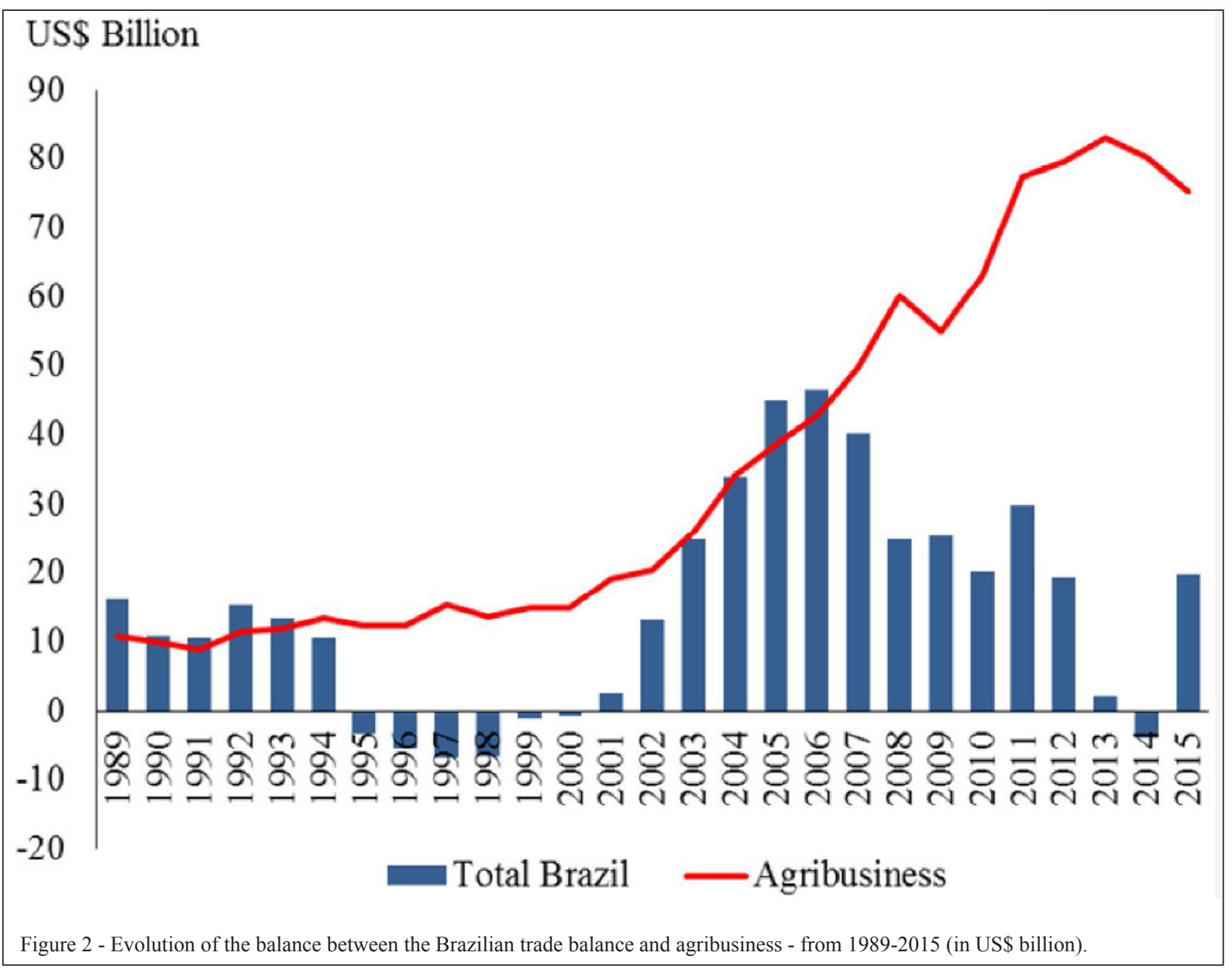

as one of top priorities in organizations across the globe (DEMO, 2010). Therefore, this aspect must also be included among the principal priorities of the companies involved in the agricultural division.

\section{Know and retain customers}

The consumer goods industry employs marketing techniques to a great extent to ensure wider publicity. Similarly, the agricultural market must take advantage of these tools exploited over the years by other business segments to advance its profitability. Even minimal efforts taken to advertise can bring in sizable sales expansions or even tap into a specific desirable market sector.

With the burgeoning number of methods and the present ease of access to information, an escalating quantity of potential customers can be made aware of the diversity of the same offer, for the same product that is available at a point in time. The question raised is what are the possibilities, in connection with the agricultural machinery and equipment sector, to ensure that the companies of this branch show increased results, which can remain stable? Is it enough only to introduce a policy change in the pricing alone? While 'price' may be a good way to draw a customer into doing business, it may not be the best method to sustain it for a long period. A significant point to bear in mind is that it costs five times less to hold onto the current customers than to acquire new ones (SOUKI, 2006). Keeping customers is equivalent to loyalty.

Particularly in the agricultural sector, any discussion on seeds, phytosanitary products, fertilizers or agricultural machinery, places high value on the product quality. Every brand boasts of having the best product; however, with the soaring investments sunk into research and development, the product quality of the different companies has been matched. Wider variations are available in the whole product range, like different sizes of new models of 
Table 1 - Internal sales of wholesale agricultural machinery - (2000 to 2015).

\begin{tabular}{|c|c|c|c|c|c|c|}
\hline Year & Motorized cultivators & Wheel Tractors & Crawler Tractors & Harvesters & Backhoe Loaders & Total \\
\hline 2000 & 722 & 24.591 & 592 & 3.780 & 1.377 & 31.062 \\
\hline 2001 & 856 & 28.203 & 496 & 4.098 & 1.870 & 35.523 \\
\hline 2002 & 1.050 & 33.217 & 551 & 5.648 & 2.102 & 42.568 \\
\hline 2003 & 1.585 & 29.476 & 449 & 5.440 & 1.045 & 37.995 \\
\hline 2004 & 1.682 & 28.803 & 526 & 5.605 & 1.174 & 37.790 \\
\hline 2005 & 2.141 & 17.729 & 408 & 1.534 & 1.410 & 23.222 \\
\hline 2006 & 1.857 & 20.435 & 300 & 1.030 & 2.050 & 25.672 \\
\hline 2007 & 1.548 & 31.300 & 437 & 2.377 & 2.675 & 38.337 \\
\hline 2008 & 1.852 & 43.414 & 720 & 4.458 & 4.028 & 54.472 \\
\hline 2009 & 1.759 & 45.437 & 618 & 3.817 & 3.681 & 55.312 \\
\hline 2010 & 1.807 & 56.420 & 878 & 4.549 & 4.871 & 68.525 \\
\hline 2011 & 1.307 & 52.296 & 1.022 & 5.343 & 5.355 & 65.323 \\
\hline 2012 & 1.348 & 55.819 & 1.062 & 6.278 & 5.632 & 70.139 \\
\hline 2013 & 1.618 & 65.089 & 942 & 8.539 & 6.804 & 82.992 \\
\hline 2014 & 1.553 & 55.612 & 835 & 6.448 & 4.161 & 68.609 \\
\hline 2015 & 1.059 & 37.381 & 380 & 3.917 & 2.258 & 44.995 \\
\hline
\end{tabular}

Source: ANFAVEA, 2016.

agricultural machines, in keeping market demands. This factor; however, is controlled by industries, and not by the product supplier, which in this case is the resale of agricultural machinery.

A manager of a reseller must work around several limitations, particularly in the area of pricing, because the factory provides the price lists. Neither can he change the quality or product range. Another factor that the manufacturer anticipates is marketing the factory which makes the products; however, to boost the resale market, the manager will need to develop his own specific marketing strategies, apart from product marketing. Customers must be able to look upon the reseller as the one with the answers to their problems.

In the face of the intense competition in which the companies of the same branch vie to make offers on identical services, in order to be a cut above the others, great investment must be done in building a relationship with the clients. The same authors insisted that Relationship Marketing programs will become self-sustaining over the medium- and longterm periods, only because they enable the resources previously invested in low-value customers to be rerouted to attract the high-value customers. In a case study done on a car dealership with respect to the implementation and application of CRM, it was very obvious that the company had fulfilled its goals by utilizing this technique. The present study deals with the findings of the researcher on a department focused on the research and evaluation of customer satisfaction (OLKOSKI et al., 2009).

Dealers in agricultural machinery ought to offer their customers a variety of services, and endeavor to optimize the quality of these services to distinguish themselves as better than their competitors. The effectiveness of such services can dramatically alter the customers' perspective of the resale, being more than just a product distributor. According to PAYNE (2006) providing an exceptional service is the main factor which clearly and consistently distinguishes one dealer from another.

KOTLER (2003) stated that building customer loyalty necessitates the capacity to distinguish between the customers as profitable and non-profitable. KOTLER also declared that companies utilize $70 \%$ of their marketing budgets on acquiring new customers, despite the proven fact that $90 \%$ of their incomes flow from the current customers. Therefore, for effective customer retention, the companies must know their expectations and meet them. CRM is; therefore, inserted into the business plan, to get to know the customers' needs and expectations.

The company as a whole unit must refocus its efforts on customer satisfaction. At every level of responsibility, right from the salesperson to director, through secretaries and technical assistants, every 
employee must completely concentrate on satisfying the customers' expectations and only then, customer relationship management be implemented. BRITO (2011) advocated that training can be given to the employees, as well as motivation to understand customer expectation and need. All the departments in the company need to be integrated in this effort, else the success of implementing CRM will be remote (SHANG \& LIN, 2010).

A company that gets to know the preferences and behavior of the potential customers will have a competitive advantage over the competitors. When the current customers and potential customers are identified, ranking them and distinguishing as the most profitable customers from this hierarchy, becomes easier. This will enable the company to decide which resale customers are to be retained. CRM thus enables the company to offer a high level of customer satisfaction by systematizing and utilizing the database containing customer information. This tool also promotes customer segmentation and thus the customization of the offers available to each segment. This raises the quality of the products and services provided, from the customers' perspective.

\section{CRM as a technological tool and examples of its implementation}

CRM is a term frequently utilized to refer to the software available in the market to acquire knowledge regarding the clients. Some companies sometimes market their software as "CRMs", causing even more confusion regarding this term. However, if the whole company fails to exhibit coherence of targeting within its structure and chooses not to implement CRM as a strategy, utilizing such software will merely be an investment with no returns. A few of the greatest obstacles encountered are the ability to synchronize the positive inputs of all the employees and utilize this information gathered from the customers. Irrespective of how elementary the customer database of the company is, if the customer data is provided and then applied, the company will definitely observe the difference. In brief, the key factor in successfully implementing CRM is customer information.

Databases providing customer information are available in the market. In fact, several companies pay a fee to access them, pick out the information relevant to their business and utilize them as best as is feasible. Reselling farm machinery involves discovering a database that contains pertinent information from farmers, like property size, machinery employed, whether they are farmerowned, and farmed products.
Software related to the sale of agricultural inputs are available, like the CRM module of Siagri AgriBusiness, which enabled characterizing the agricultural output of the rural producer, including information regarding planting date, crop type and planted area. This tool facilitates producer segmentation on the basis of the agricultural potential and historical usage of the agricultural inputs. This product is marketed to help in enhancing the sales, as well as customer relationship management of the distributors of pesticides, seeds and other agricultural inputs (SIAGRI, 2012).

While developing this study, several interviews were conducted in a significant Brazilian agricultural region on a resale of agricultural machinery. One company evinced interest in implanting CRM with the intention of offering better services to its clients. This particular resale extended across 62 municipalities, which revealed wide heterogeneity within this area. During the course of interviewing the management of the company, the issues raised were regarding their interest and importance in getting to know their customers better, updating their contact history and modifying the offers to suit the customer. The management; however, raised the possibility of encountering obstacles in the process of implementing CRM, particularly from the employees, who because of their traditionalist mindset, would be wary of any type of change. The reseller needs to explore the many kinds of systems marketed by the technology companies and determines the best means of, not only implementing the system, but also adopting the CRM philosophy.

In the course of this study, we came across a report from an agricultural machinery concessionaire in Presidente Prudente on the unsuccessful implementation of CRM. The case study had utilized an Enterprise Resource Planning (ERP) software for CRM and had initially migrated the company data that had been used only to track the bank issues and installment payment by the customers. The clients were then segmented according to consultant portfolio as was proposed and done, based on the service region. They were classified potentially as A, B, C or $\mathrm{D}$ depending on the level of fleet, infrastructure, credit, technology and brand acceptance of the manufacturer. Next, they held a meeting and the employees were educated on the new tool that was being implemented, which required each one of them to make a change in their approach, so that CRM could be accepted as a new culture and a mission. Only then would it be successful. However, they unexpectedly met with stiff resistance to these changes from the 
staff, which made it very hard to implement CRM. Just eight months after its implementation, due to the poor understanding of the concept, noncompliance of all the employees with the process and the inaccurate reports given, the strategic sector discredited in the partnership with the company that had developed the CRM system. Although, the company had invested substantially, the concessionaire broke the contract and reverted to the former methods and processes (BARBATTO JUNIOR \& POLIDORIO, 2013).

In their research, EBERLE et al. (2009) reported that a service provider had been unsuccessful in implementing the CRM system. The authors cited problems with IT, hurdles in the organizational culture and a poor understanding of the tool itself as the principal causes for their failure in adopting the CRM, highlighting account for return on investment. According to the case study, the CRM essentially operated in Brazil, with the only goal of enhancing its registration to comply with demands of the customer service center for more data on the customers. The challenge these Brazilian companies face in implementing CRM is to optimize their relationship with the customers to enable the adequacy of decision-making and development of strategies (EBERLE et al., 2009).

One more instance cited from the Brazilian agricultural sector was a case study which focused on the implementation of a loyalty program in a multinational dealing with agricultural pesticides. The study showed that; although, the company claimed to build the customer database, in practice it was slanted towards the product. From the same study, it became clear that improvements were necessary in the area of communication with the customers, as well as the prevailing restrictions encountered because of the turnover of the sellers (ROCHA et al., 2008). The company was to periodically check that the clients' perception of it concurred with the image that it wished to portray.

\section{RECOMMENDATIONS}

When dealing with the resale of agricultural machines, the marketing strategies are generally focused on the product; as they are convinced that their product is the real differential between it and that of the competitors, it is advisable to establish their own information database, including information that is more relevant to the agricultural machinery sector and the area served by the concessionaire. It is not easy to create, maintain and update a database of the existing and potential customers. It should be started with the insertion of the data regarding the clients from a municipality, a specific area or a single vendor. Gradually, all the customers will get included.

It is crucial to update and train all the staff to enable them to utilize the database. If merely collection of the existing information is the goal, and planning its use does not feature in the plan, then the time and money invested in creating the database are wasted. In the scenario of the resale of agricultural machinery, the data is gathered principally through the sellers. The salespeople have the most contact with and the confidence of the customers. Sellers should be in a position to bring in the initial information required for first creating the database and then updating it.

A $\log$ must be created to record the vendors' visits and calls. All the new information in the database must be entered by them, for which they must be rewarded. The important farmers in the region serviced by the seller must be identified and investigated; sellers may also be given incentives for focusing on the farmers who may be the wealthiest, most influential or those who more frequently make changes in their implements.

By implementing CRM and through the commitment of all the employees at all levels of the company to this strategy, it is feasible to get to know and segment the clients. It then becomes easier to plan and systematize all the contacts made and followed up with these clients, and maintain a history of the conversations with them and a record of the employees' perceptions of them. These communications enabled the company to know if the customer is satisfied with the products and services it offers, and if the company has met the customer's expectations. This can also help to raise the degree of trust a customer reposes in the company, by maintaining contact and evincing concern with the lived experiences between client and company.

Creating an agribusiness customer information base offers several significant benefits. One advantage is that because this sector depends greatly on human capital, which is migratory, the information stored becomes useful. Most frequently, companies in this industry lose information on the history of the customer and his purchases when a seller or representative neglects to serve a particular area. Therefore, when a database is set up and records the customer contact history, including basic information like contact address and phone number, even a simple glance through a visitation journal will afford the company some information; however, minimum, which would encourage it to continue its 
strategy, and provide the customer his needs, and meet his expectations.

Post-sale follow-up is another noteworthy aspect while planning and implementing CRM in an agricultural machinery dealership. All data on the customers and their purchases need to be stored in the system, in addition to the first usage impressions (which must be gathered by the vendor after periodically accessing it, post-sale) and the maintenance history. Resale must be a proactive process and the customer must be accessed at the specified time of preventive maintenance, constantly updating the customer's judgment on the product. These steps must be taken with the intention of bolstering the image of resale as a problem solver, rather than it being recalled to memory only at the point of exchange of machinery. According to OLKOSKI et al. (2009) regarding the case study of a car dealership, the post-sale was perceived as the significant factor in customer loyalty. The data of the concessionaire highlighted the fact that the customer could be periodically accessed at suitable times, which are normally when the clients change their cars or when preventive maintenance is required.

\section{CONCLUSION}

All agricultural companies, including those concerned with agricultural machinery resale, must adopt Customer Relationship Management as a tool by which they get to know their customers. This will facilitate them to adequately meet the customers' expectations and thus ensure their loyalty. CRM must be approached as a mission or business technique, more than as just a concept or a tool, and the whole company must adopt it.

As the dealers of farm machines face restrictions in determining the price and range of their products, they need to invest in marketing methods that will improve the image of resale. The customer must understand resale as a problem solver; and the dealer must be always available or easy to contact, and ready to serve the customers.

When the dealer surmounts the barrier of acquiring the farmers' information, the greater hardship of applying CRM in the case of the resale of agricultural machinery and implements, will possibly be how to utilize the information they have gathered. Only if the company is able to systematize all its data will there be a richer relationship between the company and the customer; apart from this, all the employees of the company must closely follow the technique of relating to the customer, as this is fundamental for the
CRM to be successful in retaining the customers and produce the desired improvement in the outcome. In this instance, the information gathered by the sales team will prove highly beneficial in understanding the type of machinery that the farmers possess or desire to purchase. Besides, maintaining aftersale connections with the customer facilitates the assessment of expectation versus service, with the intention of always retaining the customer.

\section{REFERENCES}

ANFAVEA (ASSOCIACC̃̃O NACIONAL DOS FABRICANTES DE VEÍCULOS AUTOMOTORES). Anuário Da Indústria Automobilística Brasileira - Brazilian Automotive Industry Yearbook 2016. São Paulo, 2016. 154 p.

BARBATTO JUNIOR, L.R.; POLIDORIO, G.R.S. Como quebrar paradigmas sem causar um impacto negativo no processo de implantação do marketing de relacionamento, CRM e DBM empresarial: Um estudo de caso. In: ETIC - ENCONTRO DE INICIAÇÃO CIENTÍFICA DAS FACULDADES INTEGRADAS “ANTONIO EUFRÁSIO DE TOLEDO”2013, Presidente Prudente, SP. Anais... Presidente Prudente: ETIC, 2013. V.9, n.9. Available from: <http://intertemas.toledoprudente.edu.br/revista/index.php/ ETIC/article/viewFile/3371/3122>. Accessed: May 18, 2016.

BRITO, C. Relationship marketing - Old wine in a new bottle? Innovative Marketing, v.7, n.1, p.66-77. 2011. Available from: $<$ https://sigarra.up.pt/reitoria/pt/pub geral.show file?pi gdoc $\mathrm{id}=125042>$. Accessed: May 18, 2016 .

CEPEA (CENTRO DE ESTUDOS AVANÇADOS EM ECONOMIA APLICADA). Relatório PibAgroBrasil. GDP Agribusiness - Brazil Outlook. 2016. Available from: <http:// www.cepea.esalq.usp.br/comunicacao/Cepea_PIB_BR_jan16. pdf $>$. Accessed: May 17, 2016.

DEMO, G. Políticas de gestão de pessoas nas organizações: o papel dos valores pessoais e da justiça organizacional. 3.ed. São Paulo: Atlas, 2010. 192 p.

EBERLE, L. et al. A incorporação de um sistema de CRM na prática gerencial em uma empresa prestadora de serviços da Serra Gaúcha. In: SIMPÓSO DE EXCELÊNCIA EM GESTÃO E TECNOlOGIA, 6., 2009, Resende, RJ. Anais... Resende: Associação Educacional Dom Bosco 2009. Available from: $<\mathrm{http}: / /$ www.aedb.br/seget/arquivos/artigos09/548_548_245_Artigo_ CRM - Seget.pdf $>$. Accessed: May 17, 2016.

KOTLER, P. Marketing de A a Z: 80 conceitos que todo profissional precisa saber. 10. Impr. Rio de Janeiro: Elsevier, 2003. $251 \mathrm{p}$.

KRASNIKOV, A. et al. The impact of Customer Relationship Management implementation on cost and profit efficiencies: evidence from the US commercial banking industry. Journal of Marketing, v.73, n.6, p.61-67, 2009. Available from: $<$ http://www. jstor.org/stable/20619059>. Accessed: May 19, 2016.

MAPA (MINISTÉRIO DA AGRICULTURA, PECUÁRIA E ABASTECIMENTO). Balança comercial - Série histórica (1989-2015). Available from: <http://www.agricultura.gov.br/ 
internacional/indicadores-e-estatisticas/balanca-comercial $>$. Accessed: May 17, 2016.

NGUYEN, B.; MUTUM, D.S. A review of customer relationship management: successes, advances, pitfalls and futures. Business Process Management Journal, v.18, n.3, p.400-419, 2002. Available from: <http://www.emeraldinsight.com/doi/ abs/10.1108/14637151211232614>. Accessed: May 17, 2016.

OLKOSKI, G. et al. Relationship marketing and CRM software: a case study in a car dealer. Revista de Administração da UFSM, v.2, n.3, p.417-432, 2009. Available from: <http://www. spell.org.br/documentos/ver/5113/marketing-de-relacionamentoe-software-de-crm--estudo-de-caso-em-uma-concessionaria-deautomoveis/i/pt-br>. Accessed: Jun. 14, 2016.

PAYNE, A. Handbook of CRM: achieving excellence in customer management. Oxford: Elsevier, 2006. 458 p.

PEPPERS AND ROGERS GROUP DO BRASIL. CRM SeriesMarketing 1 to 1. São Paulo: Makron Books, 2001. 110 p.
ROCHA, T.V. et al. Customer perception about loyalty programs in agricultural market: a case study. Revista Brasileira de Gestão de Negócios, v.10, n.28, p.282-294, 2008. Available from: <http:// www.spell.org.br/documentos/ver/6539/a-percepcao-dos-clientesagricolas-sobre-os-programas-de-fidelidade--um-estudo-de-caso/i/ pt-br>. Accessed: Jun. 14, 2016.

SHANG, S.S.C.; LIN, S.F. People-driven processes in customer relationship management. The Service Industries Journal, v.30, n.14, p.2441-2456, 2010.

SIAGRI - Software para agronegócio. Levantamento de mercado e segmentação de clientes por produção agrícola. Available from: <http:/www.siagri.com.br/bis/2012/novembro/ levantamentoMercado.pdf $>$. Accessed: Jun. 01, 2015.

SOUKI, O. As 7 chaves da fidelização de clientes. São Paulo: Harbra, 2006. 128 p.

STRAUSS, J.; FROST, R. Customer relationship management. E-marketing. 2.ed. New York: Prentice Hall, 2002. 519 p. 